IZA DP No. 8045

Effect of Sexual Orientation on Job Satisfaction: Evidence from Greece

Nick Drydakis

March 2014 


\title{
Effect of Sexual Orientation on Job Satisfaction: Evidence from Greece
}

\author{
Nick Drydakis \\ Anglia Ruskin University \\ and IZA
}

\section{Discussion Paper No. 8045 \\ March 2014}

\author{
IZA \\ P.O. Box 7240 \\ 53072 Bonn \\ Germany \\ Phone: +49-228-3894-0 \\ Fax: +49-228-3894-180 \\ E-mail: iza@iza.org
}

Any opinions expressed here are those of the author(s) and not those of IZA. Research published in this series may include views on policy, but the institute itself takes no institutional policy positions. The IZA research network is committed to the IZA Guiding Principles of Research Integrity.

The Institute for the Study of Labor (IZA) in Bonn is a local and virtual international research center and a place of communication between science, politics and business. IZA is an independent nonprofit organization supported by Deutsche Post Foundation. The center is associated with the University of Bonn and offers a stimulating research environment through its international network, workshops and conferences, data service, project support, research visits and doctoral program. IZA engages in (i) original and internationally competitive research in all fields of labor economics, (ii) development of policy concepts, and (iii) dissemination of research results and concepts to the interested public.

IZA Discussion Papers often represent preliminary work and are circulated to encourage discussion. Citation of such a paper should account for its provisional character. A revised version may be available directly from the author. 


\section{ABSTRACT \\ Effect of Sexual Orientation on Job Satisfaction: Evidence from Greece}

This study investigates the differences in four aspects of job satisfaction between gay men/lesbians and heterosexuals. The analysis results suggest that gay men and lesbians are less satisfied with their jobs, by all job satisfaction measures, than heterosexual employees, all other factors being held constant. Gay men and lesbians who have disclosed their sexual orientation at their present job are more satisfied with their jobs than those who have not. In addition, gay men and lesbians who disclosed their sexual orientation at their current workplace longer ago are more satisfied with their jobs than gay men and lesbians who disclosed their sexual orientation more recently. Moreover, adverse mental health symptoms have the same negative impact on employees' job satisfaction regardless of sexual orientation. Furthermore, gay men and lesbians receive lower wages than comparable heterosexual employees. Whilst, the wage gap due to sexual orientation is greater in the group of very dissatisfied men than in the group of very satisfied men, and gay men and lesbians who have disclosed their sexual orientation at their present job receive lower wages than those who have not, but they still have higher levels of job satisfaction. It seems that the effect of disclosure on job satisfaction is the net effect of the connections between disclosure and job satisfaction.

JEL Classification: J28, C93, J7, J16, J31, J42, J64, J71

Keywords: job satisfaction, sexual orientation

Corresponding author:

Nick Drydakis

Lord Ashcroft International Business School

Anglia Ruskin University

East Road

Cambridge, BB1 1PT

United Kingdom

E-mail: nick.drydakis@anglia.ac.uk

\footnotetext{
* I thank Prof. Lee Badgett and Prof. Christopher Carpenter for their helpful advice and comments. Also I acknowledge benefit from two anonymous referees whose comments and suggestions have significantly contributed to improve upon previous versions of this paper. I have greatly benefited from comments and suggestions of participants at the workshop Sexual Orientation Discrimination in the Labor Market, Paris 2012, on an early draft of the paper.
} 


\section{Introduction}

Previous socio-economic research on job satisfaction ${ }^{1}$ has addressed heterogeneous effects between sexes (Clark 1997; Gazioglu and Tansel, 2006), health conditions (Uppal, 2005; Drydakis, 2012a) and ethnicities (Campbell, 2011). The current study examines the relation between job satisfaction and sexual orientation, utilizing data from the 2008-2010 Athens Area Study Wave. The current paper adds to the literature with a dataset that specifically questions male and female employees on four aspects of job satisfaction: satisfaction with total pay, satisfaction with promotion prospects, satisfaction with respect received from one's supervisor, and total job satisfaction. In the current study, to determine whether a job satisfaction gap exists, the job satisfaction of gay men/lesbian employees is compared to the job satisfaction of heterosexual employees, holding all other factors constant (Clark, 1997). The 20082010 AAS Wave includes a large number of control variables, such as education, age, sexual orientation, job characteristics, objective health conditions, and adverse mental health symptoms. These variables are correlated with job satisfaction, so their inclusion is important when studying the relation between sexual orientation and job satisfaction (Clark, 1996). In addition, the 2008-2010 AAS Wave includes information on two

\footnotetext{
${ }^{1}$ The construct of job satisfaction is generally defined as a positive emotional state that reflects an affective response to a job situation (Locke, 1976, 1984). There are two types of job satisfaction (Mueller and Kim, 2008): global job satisfaction, which refers to employees' overall feeling about their jobs, and job facet satisfaction, which refers to feelings about specific job aspects, such as wages, promotion prospects, and the quality of the relationships with one's supervisor and co-workers (Spector, 2008).
} 
different aspects of sexual orientation, namely, openness about being homosexual at the current workplace and years since coming out as a gay man/lesbian at the current job. It is possible to take advantage of this rich information to evaluate the job satisfaction of sexual orientation minorities and offer new outcomes.

Data limitations in Greece remain a major obstacle to research on the gay and lesbian population. Only three studies have focused on the labor market success of sexual orientation minorities. Drydakis (2009) and Drydakis (2011) found that gay men and lesbians face lower occupational access and are offered lower entry wages, while Drydakis (2012b) estimates that gay and bisexual men face a higher unemployment rate and receive lower monthly wages than their heterosexual counterparts. The above findings indicate that the current social situation of gay/bisexual and lesbian people represents a problem for Greece. Research studies in the US and EU suggest that gay men and lesbians who are subject to unequal treatment at work describe a variety of experiences that range from discomfort and signs of embarrassment on the part of managers and colleagues to exclusion and insults by colleagues (Sears and Mallory, 2011; Badgett et al., 2007; European Union Agency for Fundamental Rights report, 2009). Moreover, researchers recount instances of institutionalized procedures to restrict officially conferred work rewards, such as promotions, salary increases and increased job responsibilities (Badgett et al., 2007). In view of these facts, one might expect that gay men and lesbians are more likely to report lower job satisfaction. Discrimination is believed to increase workplace dissatisfaction ${ }^{2}$ (Bocherman and Ilmakunnas, 2009;

\footnotetext{
${ }^{2}$ There is evidence that job satisfaction may be an important variable in the inequality in the overall returns of work (Bockerman and Ilmakunnas, 2009; Hamermesh, 2001; Ensher et al. 2001; Drydakis, 2012c). Studies show that racial discrimination and sexual
} 
Mirage, 1994; Sanchez and Brock, 1996). The rationale for such low expectations is the disadvantaged position of gay men and lesbians in the labor market, so we also specifically consider the role of wage differentials by sexual orientation. The first hypothesis related to job satisfaction and sexual orientation minorities is the following:

Hypothesis 1: Gay men and lesbians are more likely to report lower job satisfaction than heterosexuals.

In addition, studies suggest that stigma has negative consequences for the physical health of stigmatized people (Major and O’ Brien, 2005; Allport, 1954; Clark et al., 1999). Stigma is a universal feature of gay and lesbian lives ${ }^{3}$ (Balsam and Mohr, 2007). Studies have shown that gay men and lesbians experience adverse mental health symptoms, such as depression, ego defenses, low self-esteem, and external locus of control (Rosser et al., 2008; Koh, 2006; Biernbaum and Ruscio, 2004; Meyer, 2003). One might expect that adverse mental health symptoms affect the job satisfaction of

discrimination at the workplace contribute to higher work tension and job stress and decreased job satisfaction and organizational commitment (Sanchez and Brock, 1996; Mays et al. 1996; Shields and Wheatley Price, 2002a; 2002b).

${ }^{3}$ Research studies have demonstrated the existence of sexual stigma (the shared knowledge of society's negative regard for any behavior, identity, relationship or community that is not heterosexual), heterosexism (the cultural ideology that perpetuates sexual stigma), and sexual prejudice (negative attitudes based on sexual orientation), as well as the effects that such attitudes have on the everyday experiences of gay men and lesbians (Herek, 2000). 
sexual orientation minorities more than the job satisfaction of heterosexuals because gay men and lesbians are subject to the effect of stigma (Bowling et al., 2010; and Watanabe, 1993; Major and O’ Brien, 2005). The second hypothesis related to job satisfaction, adverse mental health symptoms and sexual orientation minorities is the following:

Hypothesis 2: Adverse mental health symptoms are likely to have greater negative effects on the job satisfaction of gay men and lesbians than on the job satisfaction of heterosexuals.

In addition, studies view disclosure as a dichotomous variable, wherein one either has or has not shared one's sexual orientation with a person (Morris, et al. 2001). Secrecy creates a large amount of stress and anxiety for gay and lesbian employees (Walster et al., 1978). Keeping one's sexual identity secret results in feeling misunderstood, pressured, detached and alienated, which may culminate in a desire to leave the organization (Moradi, 2009; Watson and Platt, 2006; Day and Schoenrade, 2000). On the other hand, studies confirm that gay and lesbian employees experience lower job stress, depression, anxiety, negative psychological symptoms and conflict between work and home the longer that they are open about their sexual orientation at work (Wright and Perry, 2006; Button, 2001; Day and Schoenrade, 2000; Ellies and Riggle, 1996). Gay men and lesbians who are out to workplace colleagues have positive work attitudes that enable them to feel confident; foster a happier work experience; foster commitments, openness, and interaction with colleagues; improve productivity; and reward and encourage supportive organizational policies (Juster et al., 2013; Griffith and Hebl, 2002; Day and Schoenrade, 1997). Based on these patterns, the third 
and fourth hypotheses related to job satisfaction, sexual orientation minorities and openness are the following:

Hypothesis 3: Gay men and lesbians who are open about their sexual orientation at their current workplace are more likely to report higher job satisfaction than gay men and lesbians who are not open about their sexual orientation at their current workplace.

Hypothesis 4: Gay men and lesbians who have been open about their sexual orientation at their current workplace for longer periods of time are more likely to report higher job satisfaction than gay men and lesbians who have been open about their sexual orientation at their current workplace for shorter periods of time.

Several issues within the workplace environment may have a potential influence on the job satisfaction of gay men and lesbians. In the current study, we aim to examine whether adverse mental health symptoms, disclosure of sexual orientation at the current job, and years since coming out at the current job may affect sexual orientation minorities' job satisfaction levels. Job satisfaction is a crucial factor not only to organizations but also to employees. People, regardless of their sexual orientations, deserve to be treated fairly and with respect, and job satisfaction can be indicative of good treatment (Spector, 2008; Mount et al., 2006; Faragher et al., 2005). On the other hand, organizational functioning can also be affected by job satisfaction through positive and/or negative behaviors of employees (Spector, 2008; Judge and Bono, 2001; Syptak, et al., 1999). Motivated employees are crucial to an organization’s success, and therefore, understanding gay men and lesbians in their jobs could be a driving force in strengthening organizational commitment. 
The remainder of the paper is divided into three sections. The next section briefly discusses the descriptive statistics. Section 3 presents the empirical estimations and offers a discussion. The last section concludes the study.

\section{Descriptive Statistics}

The data used in this study were gathered from March 2008 to February 2010 in Athens, the capital of Greece, as part of the Athens Area Study (2008-2010 AAS Wave) conducted by the University of Piraeus, the University of Central Greece and the Panteion University of Social and Political Sciences. The 2008-2010 AAS is one component of the Multi-City Study of the Scientific Centre for the Study of Discrimination (SCSD). The current AAS Wave consists of telephone-based surveys. Individuals in each household were randomly selected to provide information on a variety of demographic characteristics, and the analysis was restricted to employed respondents aged 18 to 65 years (the upper limit corresponding to the official retirement age in Greece). The SCSD guards participants’ anonymity in all research output. For convenience, all variable definitions are summarized in Table 1.

\section{[Table 1]}

Regarding the most important variables in the 2008-2010 AAS, sexual orientation and job satisfaction, the AAS includes direct questions about an individual's sexual orientation and job satisfaction. To investigate sexual orientation, employees were asked: "The next question is about sexual orientation: Do you consider yourself to be: (1) Heterosexual? (2) Gay/Lesbian? (3) Bisexual?” Carpenter (2005a) argues that direct self-reports of sexual orientation offer a measure of sexuality that, in the context of labor market analyses, is preferable to the behavioral measures used in most previous 
research. Self-reported sexual orientation is almost surely closer to workplace disclosure than is same-sex sexual behavior, in large part because the latter is likely to be less observable to employers. Furthermore, in the 2008-2010 AAS Wave, whenever the individual was identified as belonging to a sexual orientation minority, two further questions were raised, and their responses were coded as additional variables. The survey measured whether the individual was open about his/her homosexuality/bisexuality at work and the number of years since the respondent disclosed his or her sexual orientation at the his or her present workplace.

In addition, four measures of job satisfaction are included in the 2008-2010 AAS dataset. The measures are total pay (including any overtime or bonuses), promotion prospects, respect received from supervisors, and total job satisfaction. There are many methods of measuring job satisfaction, the most common of which is the Likert scale (1932). The AAS follows the format of a typical five-level Likert item. The job facet satisfaction question reads, “I'm going to read you four aspects of jobs, and for each one, I'd like you to tell me which number best describes how satisfied or dissatisfied you are with that particular aspect of your own present job.” Employees are asked to rate each job aspect on a scale from 1, "very dissatisfied," to 5, "very satisfied.”

The 2008-2010 AAS sample consists of 11,571 heterosexual employees, 540 gay men and lesbian employees (4.43\%), and 66 bisexual employees (0.54\%). Columns 1 and 2 in Table 2 show descriptive statistics for heterosexual and gay men, 
respectively. Columns 3 and 4 in Table 2 show descriptive statistics for heterosexual and lesbian women, respectively ${ }^{4}$.

\section{[Table 2]}

We observe that gay men and lesbians are less likely to be married than heterosexuals and have fewer children than heterosexuals. Gay men/lesbians and heterosexual employees experience approximately the same adverse mental health symptoms. On average, lesbian employees were found to be more educated than heterosexual women. On the other hand, gay male employees were found to be less educated than heterosexual men. In addition, gay men are more likely to be employed in blue-collar jobs and less likely to work in the service industry than heterosexual men. We observe also that gay men and lesbian employees receive lower hourly wages than heterosexuals.

Tables 3 and 4 show the reported levels of job satisfaction in the AAS survey. For heterosexual men and women, the most frequent response for all measures of job satisfaction is "satisfied." However, for gay men and lesbians, the most frequent response in all measures is "neither dissatisfied nor satisfied." For gay men and lesbians, "very dissatisfied” and “dissatisfied” responses are common, especially for satisfaction with promotion prospects and respect received from the supervisor. For both groups, “very satisfied” responses are rare, except for respect received from the supervisor for heterosexual employees.

\section{[Table 3] - [Table 4]}

\footnotetext{
44 Due to the limited number of observations, a statistical comparison between heterosexual and bisexual employees is not undertaken. In the regression stage we include bisexuals.
} 
Because this study addresses satisfaction, it might be of interest to concentrate on the "satisfied" option. As shown in the tables, heterosexual employees are always more "satisfied" than gay men and lesbian employees with respect to the four dimensions of job satisfaction, and women are always more "satisfied" than men. To be specific, 33.17\% (39.49\%) of heterosexual men (women) are "satisfied" with their total pay, 35.13\% (40.27\%) are "satisfied" with their promotion prospects, 37.06\% (42.73\%) are "satisfied" with the respect received from their supervisor, and 34.83\% (37.16\%) are "satisfied" in terms of total job satisfaction. However, only $10.98 \%$ (12.31\%) of gay men (lesbians) are "satisfied” with their total pay, 17.05\% (18.20\%) are "satisfied” with their promotion prospects, $23.27 \%$ (28.18\%) are "satisfied" with the respect received from their supervisor, and $15.00 \%$ (19.41\%) are "satisfied" in terms of total job satisfaction. The in-depth examination of differences in each job satisfaction category between sexes provides valuable additional information on the average outcomes. However, a multivariate analysis that considers all of the analyzed variables is necessary to determine whether there is a significant job satisfaction difference between heterosexual and gay men/lesbian employees.

\section{Estimations and discussion}

As in Clark (1997), Carpenter (2005a; 2008) and Drydakis (2012a, c), Tables 5 and 6 present the ordered probit model estimates of job satisfaction. The regression results confirm the initial descriptive statistics. Gay men and lesbians are less satisfied than heterosexual employees according to all measures of job satisfaction. Hypothesis 1 , that gay men and lesbians are more likely to report lower job satisfaction than heterosexuals, is accepted. The largest difference is found for satisfaction with the 
respect received from one's supervisor, followed by satisfaction with promotion prospects and satisfaction with total pay ${ }^{5}$. The current findings highlight sexual orientation minorities' dissatisfaction with their workplaces, which is consistent with Carpenter (2008) and Drydakis (2012c). In the AAS, a straightforward relationship seems to hold; because the general patterns in Greece suggest that gay men and lesbian employees face discriminatory treatment in the labor market, are victims of harassment, and enjoy lower societal approval and rewards than heterosexuals, sexual orientation minorities will report being significantly less satisfied at work (Drydakis 2009; 2011; $2012 b)^{6}$. In a later section we explicitly consider the role of wage differentials that might be related to discrimination.

\section{[Table 5] - [Table 6]}

\footnotetext{
${ }^{5}$ Similarly, bisexual men and women are estimated to be less satisfied than heterosexual employees according to all measures of job satisfaction. However, the pattern in this study should not be critically examined because the dataset includes only 54 observations of self-reported bisexual men and 12 observations of self-reported bisexual women.

${ }^{6}$ Note that studies originating from the US and the UK suggest that lesbians receive higher wages (Clain and Leppel, 2001; Arabsheibani et al., 2005). One could expect lesbians in those countries to be more satisfied with their work (see, Carpenter, 2005b). Consensus among studies may be difficult to attain, due to differences in definitions of sexual orientation, countries studied, and empirical methodologies. In the current sample, however, lesbian employees are less satisfied than heterosexual women. In Greece, lesbians seem to suffer greatly from the negative attitudes with which Greek employers view lesbians (see, Drydakis, 2011).
} 
In addition, employees with more adverse mental health symptoms are always less satisfied at work than those who have fewer of these conditions. The adverse mental health symptoms variable measures whether the employee feels depressed, unhappy, lonely, or sad or does not enjoy life, all of which are core features of life satisfaction and self-evaluation (Dave et al., 2008; Shenkman and Shmotkin, 2011). A term for the interaction of sexual orientation with adverse mental health symptoms was added to the regression to estimate whether adverse mental health symptoms affect the job satisfaction of gay men and lesbian employees more or less strongly. It is observed that there is no statistically significant difference in the effect of adverse mental health symptoms between heterosexuals and gay/lesbian people. Adverse mental health characteristics are found to have the same negative impact on employees' job satisfaction regardless of sexual orientation. Thus, hypothesis 2 , that adverse mental health symptoms are likely to have greater negative effects on the job satisfaction of gay men and lesbians than on the job satisfaction of heterosexuals, is rejected. For convenience, the same pattern can be obtained by regressing each sexual orientation group separately ${ }^{7}$.

\footnotetext{
${ }^{7}$ For instance, we report here the adverse mental health symptoms coefficient for the total job satisfaction construct. For heterosexual men (women), the coefficient is estimated to be -0.010 , s.e. $0.004^{* * *}\left(-0.012\right.$, s.e. $\left.0.004^{* * *}\right)$, whereas for gay men (lesbians), the coefficient is estimated to be -0.010 , s.e. $0.005^{* * *}(-0.011$, s.e. $\left.0.004^{* * *}\right)$. The magnitude and significance of the coefficients do not vary across sexual orientations (each result is the outcome of a separate regression). Tables are available upon request.
} 
Based on numerous theoretical perspectives, one could expect gay men's/lesbians' adverse mental health symptoms to have greater negative effects on every dependent variable related to the effect of those symptoms on heterosexuals because gay men and lesbians are subject to bias (Allport, 1954; Crocker and Major, 1989; Major and O’ Brien, 2005). However, the study’s findings suggest that (1) gay men/lesbian and heterosexual employees have approximately the same adverse mental health symptoms (see Table 2) and that (2) the effects of adverse mental health symptoms on job satisfaction are comparable for gay men/lesbians and heterosexuals. However, we have to highlight that the AAS sample addresses adult employees who were willing to disclose their sexual orientation, at least in this study. Note also that approximately $67 \%$ of the gay men and lesbian individuals in the 2008-2010 AAS sample stated that they had disclosed their sexual orientation at their present workplace. Research conducted outside and inside the workplace has shown that those individuals who disclose their homosexual identity to others tend to be better adjusted psychologically and enjoy greater life satisfaction (see Ellis and Riggle, 1996a; Griffith and Hebl, 2002). These factors are likely to contribute to the equal magnitudes of the effect of adverse mental health symptoms on job satisfaction in heterosexuals and gay men/lesbians.

In the equations for all four measures of job satisfaction, we observe that higher wages are positively correlated with higher job satisfaction. The strongest relationship is found between hourly wage and satisfaction with the respect received from one's supervisor. White-collar employees were found to be significantly more satisfied with the promotion prospects and respect received from their supervisors than blue-collar employees. However, white-collar employees report significantly less satisfaction with 
their total pay than blue-collar employees ${ }^{8}$. In addition, public employees are always more satisfied in all job satisfaction categories than private employees ${ }^{9}$ (see, Clark, 1996 and Gazioglu and Tansel, 2006). Moreover, age and the square of age are statistically significant and carry negative and positive signs, respectively, indicating a U-shaped relationship between age and job satisfaction (Clark, 1996) ${ }^{10}$. In addition, married employees appear to be significantly more satisfied at work than unmarried employees are. Immigrant employees appear to be significantly less satisfied than native employees with respect to the four aspects considered. Employees with disabilities are always less satisfied at work. Finally, employees with a university or technical school diploma are significantly less satisfied with their pay but significantly more satisfied

${ }^{8}$ Clark (1996) and Gazioglu and Tansel (2006) find that those at the higher end of the occupational scale report greater satisfaction with various aspects of their jobs but are less satisfied with their pay.

${ }^{9}$ The interactions of sexual orientation with white-collar jobs and public sector jobs were not statistically significant.

${ }^{10}$ Clark (1996) suggests that young employees may feel satisfied because they have little experience in the labor market against which to judge their own work. As they gain work experience and learn about the labor market, they are able to better judge their working conditions. With increased experience, job satisfaction drops in middle age. However, older employees may have reduced aspirations because they realize that they have limited alternative choices as they get older. 
with the respect they receive from their supervisor and with their promotion prospects ${ }^{11}$ (Clark, 1996). The patterns discussed in this section are consistent with those commonly obtained with international data (Clark, 1996; Clark, 1997; Gazioglu and Tansel, 2006).

As in Table 6, in Table 7, we present several job satisfaction regressions that consider (a) openly gay men/lesbians at their present job and heterosexuals, (b) closeted gay men/lesbians at their present job and heterosexuals, (c) openly gay men/lesbians at their present job and closeted gay men/lesbians. Gay men/lesbians who have disclosed their sexual orientation at their present jobs are always more satisfied with their jobs than those who have not. Hypothesis 3, that gay men and lesbians who are open about their sexual orientation at their current workplace are more likely to report higher job satisfaction than gay men and lesbians who are not open about their sexual orientation at their current workplace, is accepted.

\section{[Table 7]}

Similarly, in Table 8, we present additional job satisfaction regressions that consider (a) gay men/lesbians who disclosed their sexual orientation at their current workplace less than three years ago and heterosexuals, (b) gay men/lesbians who disclosed their sexual orientation at their current workplace more than three years ago and heterosexuals, and (c) gay men/lesbians who disclosed their sexual orientation at their current workplace less than three years ago versus gay men/lesbians who disclosed their sexual orientation at their current workplace more than three years ago. We expect greater job satisfaction among those with greater disclosure. A series of studies link

\footnotetext{
${ }^{11}$ Clark (1996) suggests that more educated employees have higher expectations for the pecuniary and non-pecuniary returns from their jobs and are thus more easily disappointed and dissatisfied.
} 
sexual orientation disclosure with life satisfaction and positive psychological well-being (McLaren et al. 2013; Griffith and Hebl, 2002; Button, 2001; Ragins and Cornwell, 2001). The emotional energy required to maintain the secrecy of a fundamental part of one's psychological makeup may cause anxiety, stress and job dissatisfaction (Griffith and Hebl, 2002; Day and Schoenrade, 1997).

The results in Table 8 show that gay men/lesbians who disclosed their sexual orientation at their current workplace longer ago are more satisfied with their jobs than gay men/lesbians who disclosed their sexual orientation more recently. Hypothesis 4, that gay men and lesbians who have been open about their sexual orientation at their current workplace for longer periods of time are more likely to report higher job satisfaction than gay men and lesbians who have been open about their sexual orientation at their current workplace for shorter periods of time, is accepted ${ }^{12}$. Note, however, that because our analysis does not indicate causal relationships, we cannot say with any certainty that being open about one's homosexual orientation leads to more positive attitudes.

\section{[Table 8]}

Next we consider the role of wage differentials on job satisfaction. The wage rate is the only information we have in the AAS regarding work rewards, and we sought to determine whether wage gaps between gay men and lesbian employees existed. The

12 One might presume that if employees with greater tenure are, on average, more satisfied than employees with less tenure, this relation will be partly responsible for the relationship between years of openness at a current job and job satisfaction. Unfortunately, we do not have information regarding employees' tenure to empirically test these considerations. 
results of the analysis of estimated hourly wages confirm that there are significant wage gaps for gay men and lesbian employees, holding all other factors constant. As shown in Table 9, the sexual orientation dummy variables for gay men and lesbians are negative and statistically significant. We document a significant wage gap, on the order of $4.2 \%$, for gay men. For lesbians, the estimated wage gap is approximately $8.1 \%$. Thus, a highly important pattern is revealed: the AAS sample demonstrates job satisfaction gaps and wage gaps against gay men and lesbians ${ }^{13}$.

\section{[Table 9]}

In Table 10, we estimate the sexual orientation wage difference for each satisfaction scale component for global job satisfaction. We observe that in the group of very dissatisfied men, the wage gap due to sexual orientation is larger than in the group of very satisfied men. The same pattern holds for women. The wage difference between

${ }^{13}$ In the literature, there is strong evidence of wage discrimination against gay men. Several UK and US studies estimate that gay men earn less than heterosexual men (Arabsheibani et al. 2005; Black et al., 2003). On the other hand, lesbian employees earn as much as or more than heterosexual women (Arabsheibani et al. 2005; Jepsen, 2007; Ahmed and Hammarstedt, 2010). The latter patterns can be evaluated through human capital accumulation theories and specialization choices, household formation, work effort, location, spending, and personality characteristics (Arabsheibani et al. 2005; Jepsen, 2007). In the current study, however, lesbians are found to face significant wage gaps. Greece is perceived to be highly reluctant to address issues such as sexual orientation in the labor market, and it is also ranked as the most puritanical society in Europe with respect to attitudes toward homosexuality (Eurobarometer, 2006; 2007). These patterns may affect the wage gap for lesbians. 
gay men and heterosexuals occasionally becomes statistically insignificant for those who reported being satisfied or very satisfied across the job satisfaction measures. Studies suggest that employees who perceive that rewards are equitably allocated tend to report more positive attitudes at work and vice versa (Miceli and Lane, 1991; Greenberg, 1988; Bockerman and Ilmakunnas, 2009; Hamermesh, 2001). We must stress, however, that it is not clear whether the wage gap drives satisfaction or satisfaction drives productivity differently by sexual orientation, thereby driving the wage gap. All of these patterns demonstrate the nature of multifaceted relationships and the need to explore them carefully.

\section{[Table 10]}

Based on the equity theory (Walster et al., 1978; Watson and Platt, 2006), variations in communication of one's sexual orientation may have implications for job satisfaction. Because openly gay men and lesbians have been reported to have "tested the waters” regarding unbiased evaluations in their firms before coming out, we expect them to experience more positive job satisfaction (Walster et al., 1978; Day and Schoenrade, 1997). On the other hand, gay men and lesbians who have not revealed their sexual orientation are concerned about possible inequities associated with identification of their sexual orientation. In Table 11, we show that those gay men and lesbians who have not disclosed their sexual orientation at their current workplace receive higher wages than those who are openly gay men/lesbians. The estimates suggest that openly gay men (lesbians) receive 3.1\% (5.3\%) lower wages than closeted gay men, all other things being equal. Similarly, Ellis and Riggle (1996b) show that those gay men/lesbians who had not disclosed their sexual orientation tended to make more money. In addition, we observe that the number of years since coming out at the 
present workplace has a positive impact on gay men and lesbian employees’ wages. Gay men (lesbians) who have disclosed their homosexuality at their present job more than three years ago receive $1.5 \%(1.1 \%)$ higher wages than gay men (lesbians) who have disclosed their homosexuality at their present job less than three years ago, all other things being equal. This pattern can be explained again by the need for time to adapt after disclosing one's homosexuality in the workplace (Day and Schoenrade, 2000; Smith and Ingram, 2004). It seems that the time since coming out at the present workplace plays a critical role not only in the level of job satisfaction but also in wages. It is suggested that the effect of disclosure on job satisfaction found earlier is the net effect of the connections between disclosure and job satisfaction.

\section{[Table 11]}

\section{Concluding remarks}

This study addressed the issue of differences in job satisfaction by examining the extent to which four aspects of job satisfaction-satisfaction with total pay, satisfaction with promotion prospects, satisfaction with respect received from one's supervisor, and global satisfaction—vary between heterosexual and gay male/lesbian employees. Utilizing the 2008-2010 AAS Wave, the current study revealed several interesting patterns.

The analysis results suggest that the following: (1) gay men and lesbians are less satisfied with their jobs, by all job satisfaction measures, than heterosexual employees, all other factors being held constant; (2) gay men and lesbians who have disclosed their sexual orientation at their present job are more satisfied with their jobs than those who have not; (3) gay men and lesbians who disclosed their sexual orientation at their 
current workplace longer ago are more satisfied with their jobs than gay men and lesbians who disclosed their sexual orientation more recently; (4) adverse mental health symptoms have the same negative impact on employees' job satisfaction regardless of sexual orientation; (5) gay men and lesbians receive lower wages than comparable heterosexual employees; (6) the wage gap due to sexual orientation is greater in the group of very dissatisfied men than in the group of very satisfied men, and (7) gay men and lesbians who have disclosed their sexual orientation at their present job receive lower wages than those who have not, but they still have higher levels of job satisfaction. It seems that the effect of disclosure on job satisfaction is the net effect of the connections between disclosure and job satisfaction.

In view of these outcomes and European legal movements to support sexual orientation minorities, it is crucial to understand the employment experiences of heterosexual and gay/lesbian employees to support minority people's efforts to attain better living and working conditions. Because employees tend to be evaluative, they look at their work experience in terms of liking or disliking and develop feelings of satisfaction or dissatisfaction with their jobs and with the firms for which they work. The current study suggests that the satisfaction that gay men and lesbian employees derive from their jobs can be viewed as a reflection of how they respond to job characteristics.

In addition, the analysis results revealed that two critical factors should be taken into consideration when determining how satisfied a gay/lesbian employee is with his or her job. Openness about being homosexual and years since coming out at the current workplace can positively affect job satisfaction levels. Based on the observed patterns, there are specific aspects of a job that a firm can manage to increase sexual orientation 
minorities' satisfaction in the workplace (Syptak et al., 2009). Studies suggest that good relations between employers and employees increase sexual orientation minorities' openness and improve job attitudes and can benefit the firms as a whole, given that teamwork is a very important aspect of firm productivity and success (Huffman, et al., 2008; McLaren et al., 2013). Firms concerned with diversity may want to create environments in which gay and lesbian employees can be relaxed and candid about their orientation and foster a sense of belonging wherein they feel valued (Day and Schoenrade, 2000). In addition, wage policies that are clear and applied equally to all employees regardless of sexual orientation can decrease workplace dissatisfaction and increase life satisfaction (Syptak et al., 2009; Mueller and Kim, 2008; Kerber and Campbell, 1987). Firms should understand the strategic business necessity of maximizing the talents of all employees as well as the ethical mandate of equal opportunities and fairness for all (Day and Schoenrade, 2000). Recognition, both from management and from co-workers, provides external reinforcement of an individual's developing competence and self-esteem.

Finally, several limitations in our study need to be noted. The current findings are strictly applicable only to the time, place, employee demographic, and social and labor characteristics from which the sample was drawn. The job satisfaction outcomes may be different for a sample with different characteristics. Moreover, job satisfaction is a difficult concept to grasp due to its individualistic and circumstantial nature. What one employee desires from his or her work, another may not. In addition, the sexual orientation variable, as well as the job satisfaction variable, may be subject to a number of sources of bias: selective non-response, over/under-reported sexual orientation and job satisfaction, and reverse causation between wages and job satisfaction. In the current 
study, neither sample selection bias nor the links between personality characteristics were examined. In addition, the current data set is cross-sectional, enabling us to draw conclusions only concerning associations, not causes. Furthermore, we should note that employees' job satisfaction in the current study was associated with an adverse mental health symptom scale from the Center for Epidemiology Studies. We do not have valuable information based on other major scales. Finally, we do not know how the workplace atmosphere impacts employees’ job satisfaction and the disclosure behaviors of gay men and lesbian employees. Further research is required. Thus, the results of this study are simply an indication of the relationship between sexual orientation and job satisfaction; they are by no means the final word. 


\section{References}

Ahmed, A. M. and Hammarstedt, M. (2010). Sexual Orientation and Earnings: A Register Data-Based Approach to Identify Homosexuals. Journal of Population Economics, 23: 835-849.

Allport, G. (1954). The Nature of Prejudice. New York: Doubleday Anchor.

Arabsheibani, G. R. Marin, A. and Wadsworth, J. (2005). Gay Pay in the UK. Economica, 286:333-47.

Arrow, K. J. (1998). What Has Economics to Say about Racial Discrimination? Journal of Economic Perspectives, 12:91-100.

Badgett, L. M. V. Lau, H. Sears, B and Ho, D. (2007). Bias in the Workplace: Consistent Evidence of Sexual Orientation and Gender Identity Discrimination. The Williams Institute, UCLA School of Law.

Biernbaum, M. A. and Ruscio, M. (2004). Differences Between Matched Heterosexual and Non-Heterosexual College Students on Defense Mechanisms and Psychopathological Symptoms. Journal of Homosexuality, 48: 125-141.

Black, D. A., Hoda, R. M., Seth, S. and Lower, T. (2003). The Earnings Effects of Sexual Orientation. Industrial and Labour Relations Review, 56: 449-469.

Bockerman, P. and Ilmakunnas, P. (2009). Job Disamenities, Job Satisfaction, Quit Intentions, and Actual Separations: Putting the Pieces Together. Industrial Relations: A Journal of Economy and Society, 48: 73-96.

Bowling, N. A. Eschleman, K. J. and Wang, Q. (2010). A Meta-Analytic Examination of the Relationship Between Job Satisfaction and Subjective Well-Being. Journal of Occupational and Organizational Psychology, 83: 915-934. 
Button, S. (2001). Organizational Efforts to Affirm Sexual Diversity: A Cross-Level Examination. Journal of Applied Psychology, 86:17-28.

Campbell, D. G. (2011). Diversity and Job Satisfaction: Reconciling Conflicting Theories and Findings. International Journal of Applies Management and Technology, 10: 1-15.

Carpenter, C. S. (2005a). Sexual Orientation and Economic Well-Being in Canada. Mimeo, The Paul Merage School of Business, University of California, Irvine.

Carpenter, C. S. (2005b). Self-Reported Sexual Orientation and Earnings: Evidence from California. Industrial and Labour Relations Review, 58:258-273.

Carpenter, C. S. (2008). Sexual Orientation, Income, and Non-Pecuniary Economics Outcomes: New Evidence from Young Lesbians in Australia. Review of Economics of the Household, 4:391-408.

Clark, A. (1996). Job Satisfaction in Britain. British Journal of Industrial Relations, 34:189 -217.

Clark, A. (1997). Job Satisfaction and Gender: Why are Women so Happy in Work? Labour Economics, 4:341-372.

Clark, R. Anderson, N. B. Clark, V. R. and Williams, D. R. (1999). Racism as a Stressor for African Americans: A Biopsychosocial Model. American Psychologist, 54: 805-816.

Clain, S. H. and Leppel, K. (2001). An Investigation into Sexual Orientation Discrimination as an Explanation for Wage Differences. Applied Economics, 33: 37-47.

Crocker, J. and Major, B. (1989). Social Stigma and Self-Esteem: The Self-Protective Properties of Stigma. Psychological Review, 96: 608-630. 
Dave, D. Rashad, I. and Spasojevic, J. (2008). The Effects of Retirement on Physical and Mental Health Outcomes. Southern Economic Journal, 75:497-523.

Day, N. E. and Schoenrade, P. (1997). Staying in the Closet Versus Coming Out: Relationships Between Communication About Sexual Orientation and Work Attitudes. Personnel Psychology, 50, 147-168.

Day, N. E. and Schoenrade, P. (2000). The Relationship Among Reported Disclosure of Sexual Orientation, Anti-Discrimination Policies, Top Management Support and Work Attitudes of Gay and Lesbian Employees. Personnel Review, 29: 346-363.

Drydakis, N. (2009). Sexual Orientation Discrimination in the Labour Market. Labour Economics, 16:364-372.

Drydakis, N. (2011). Women's Sexual Orientation and Labor Market Outcomes in Greece. Feminist Economics, 11:89-117.

Drydakis, N. (2012a). Health Impaired Employees’ Job Satisfaction New Evidence from Athens, Greece. Applied Economics Letters, 19: 789-793.

Drydakis, N. (2012b). Sexual Orientation and Labour Relations: New Evidence from Athens, Greece. Applied Economics, 44:2653-2665.

Drydakis, N. (2012c). Men’s Sexual Orientation and Job Satisfaction. International Journal of Manpower, 33: 901-917.

Eagley, A. H. and Chaiken, S. (1993). The Psychology of Attitudes. New York: Harcourt.

Ellis, A. L. and Riggle, E. D. B. (1996a). The Relation of Job Satisfaction and Degree of Openness About One’s Sexual Orientation for Lesbians and Gay Men. Journal of Homosexuality, 30:75-85. 
Ellis, A. L. and Riggle, E. D. B. (1996b). Sexual Identity on the Job: Issues and Services. New York: Haworth Press.

Ensher, E. A. Grant-Vallone E. J., Donaldson. (2001). Effects of Perceived Discrimination on Job Satisfaction, Organizational Commitment, Organizational Citizenship Behavior and Grievances. Human Resource Development Quarterly, 12: 53-71.

Eurobarometer. (2006). Public Opinion in the European Union. Standard Eurobaromete, Wave 66. Brussels: European Commission.

Eurobarometer. (2007). Discrimination in the European Union, Wave 65.4. Brussels: European Commission.

European Commission. (2002). Employment in Europe, Chapter 5. Luxembourg: European Communities.

European Union Agency for Fundamental Rights. (2009). Homophobia and Discrimination on Grounds of Sexual Orientation and Gender Identity in the European Union Member States: Part II-The Social Situation. European Union: Vienna.

Faragher, E. B. Cass, M. Cooper, C. L. (2005). The Relationship Between Job Satisfaction and Health: a Meta-Analysis. Occupational and Environmental Medicine, 62:105-112.

Ferrer-i-Carbonell, A. (2005). Income and Well-Being: An Empirical Analysis of the Comparison Income Effect. Journal of Public Economics, 89:997-1019.

Gazioglu, S. and Tansel, A. (2006). Job satisfaction in Britain: Individual and Job Related Factors. Applied Economics, 38:1163 -1171. 
Green, F. (2010). Well-Being, Job Satisfaction and Labour Mobility. Labour Economics, 17:897-903.

Greenberg, J. (1988). Equity and Workplace Stress: A Field Experiment. Journal of Applied Psychology, 73: 606-613.

Griffith, K. H. and Hebl, M. R. (2002). The Disclosure Dilemma for Gay Men and Lesbians: “Coming Out” at Work. Journal of Applied Psychology, 87:1191-1199.

Hamermesh, D. S. (2001). The Changing Distribution of Job Satisfaction. Journal of Human Resources, 36: 1- 30.

Herek, G. M. (2000). The Psychology of Sexual Prejudice. Current Directions in Psychological Science, 9: 19-22.

Huffman, A. H. Watrous-Rodriguez, K. M. and Eden B. King, E. B. (2008). Supporting a Diverse Workforce: What Type of Support is Most Meaningful for Lesbian and Gay Employees? Human Resource Management, 47: 237-253.

Hulin, C. L. and Judge, T. A. (2003). Job Attitudes, in Borman, W. C. Ilgen, D. R. and Klimoski, R. J. (Eds.), Handbook of Industrial and Organizational Psychology (p. 255-276). Hoboken, NJ: Wiley.

Jepsen, L. K. (2007). Comparing the Earnings of Cohabiting Lesbians, Cohabiting Heterosexual Women, and Married Women: Evidence from the 2000 Census. Industrial Relations, 46: 699-727.

Judge, T. A. and Bono, J.E. (2001). Relationship of Core Self-Evaluations Traits, SelfEsteem, Generalised Self-Efficacy, Locus of Control, and Emotional Stability with Job Satisfaction and Job Performance: A Meta-Analysis. Journal of Applied Psychology, 86, 80 - 92. 
Kerber, K. W. and Campbell, J. P. (1987). Job Satisfaction: Identifying the Important Parts among Computer Sales and Service Personnel. Journal of Business and Psychology, 1: 337-352.

Koh, A. S. (2006). Comparison of Lesbian, Bisexual and Heterosexual Women. Journal of Homosexuality, 51: 33-57.

Likert, R. (1932). A Technique for the Measurement of Attitudes. Archives of Psychology, 140:1-55.

Locke, E. A. (1976). The Nature and Causes of Job Satisfaction, in Dunnette M. D. (Ed.). Handbook of Industrial and Organisational Psychology. Rand McNally, Chicago, USA.

Locke, E. A. (1984). Job Satisfaction, in Gruneberg, M. and Wall. T, (Eds.), Social Psychology and Organizational Behaviour (p. 92-117). London, England: John Willey and Sons.

Major, B. and O’ Brien, L. T. (2005). The Social Psychology of Stigma. Annual Review of Psychology, 56: 393-421.

Mays, V. M. Coleman, L. M. and Jackson, J. S. (1996). Perceived Race-Based Discrimination, Employment Status, and Job Stress in a National Sample of Black Women. Implication for Health Outcomes. Journal of Occupational Health Psychology, 1: 319-329.

McLaren, S. Gibbs, P. M. Watts, E. (2013). The Interrelations Between Age, Sense of Belonging, and Depressive Symptoms Among Australian Gay Men and Lesbians. Journal of Homosexuality, 60: 1-15. 
Miceli, M. P. and Lane, M. C. (1991). Antecedents of Pay Satisfaction: A Review and Extension. In Rowland, K. and Ferris, O. R. (Eds.), Research in Personnel and Human Resource Management (pp. 235-309). Greenwich, CT: JAI Press.

Mirage, L. (1994). Development of an Instrument Measuring Valence of Ethnicity and Perception of Discrimination. Journal of Multicultural Counseling and Development, 22:49-59.

Moradi, B. (2009). Sexual Orinetaion Disclosure, Concealment, Harassment and Military Cohesion: Perceptions of LGBT Military Veterans. Military Psychology, 21: 513-533.

Morris, J. F. Waldo, C. R. and Rothblum, E. D. (2001). A Model of Predictors and Outcomes of Outness among Lesbian and Bisexual Women. American Journal of Orthopsychiatry, 71: 61-71.

Morrison, R. (2008). Negative Relationships in the Workplace: Associations with Organisational Commitment, Cohesion, Job Satisfaction and Intention Turnover. Journal of Management and Organization, 14: 330-344.

Mount, M. Ilies, R. and Johnson, E. (2006). Relationship of Personality Traits and Counterproductive Work Behaviors: The Mediating Effects of Job Satisfaction. Personnel Psychology, 59:591-622.

Mueller, C. W. and Kim, S. W. (2008). The Contented Female Worker: Still a Paradox?. In Hegtvedt, K. A. and Clay-Warner, J. (Eds.). Justice: Advances in Group Processes (pp. 117-150). Bingley, UK: Emerald Group Publishing Limited. 
Ragins, B. R. and Cornwell, J. M. (2001). Pink Triangles: Antecedents and Consequences of Perceived Workplace Discrimination Against Gay and Lesbian Employees. Journal of Applied Psychology, 86: 1244-1261.

Rosser, S. Bockting, W. O. Ross, M. W. Miner, M. H. and Coleman, E. (2008). The Relationship Between Homosexuality, Internalized Homo-Negativity, and Mental Health in Men Who Have Sex with Men. Journal of Homosexuality, 55: 185-203.

Sanchez, J. I. and Brock, P. (1996). Outcomes of Perceived Discrimination among Hispanic Employees: Is Diversity Management a Luxury or a Necessity? Academy of Management Journal, 39:704-719.

Sears, D and Mallory, C. (2011). Documented Evidence of Employment Discrimination and its Effects on LGBT People. California: The Williams Institute.

Shields, M. and Wheatley Price, S. (2002a). The Determinants of Racial Harassment at the Workplace: Evidence from the NHS Nursing Profession. British Journal of Industrial Relations, 40: 1-21.

Shields, M. and Wheatley Price, S. (2002b). Racial Harassment, Job Satisfaction and Intentions to Quit: Evidence from the British Nursing Profession. Economica, 69: 295-326.

Smith, N. G. and Ingram, K. M. (2004). Workplace Heterosexism and Adjustment Among Lesbian, Gay, and Bisexual Individuals: The Role of Unsupportive Social Interactions. Journal of Counseling Psychology, 51:57-67.

Sousa-Poza, A. and Souza-Poza, A. A. (2003). Gender Differences in Job Satisfaction in Great Britain, 1991-2000: Permanent or Transitory? Applied Economics Letters, 10:691-694. 
Spector, P. (2008). Industrial and Organisational Behaviour. New Jersey: John Wiley and Sons.

Syptak, J. M. Marsland, D. W and Ulmer, D. (1999). Job Satisfaction: Putting Theory into Practice. Family Practice Management 6: 26-30.

Uppal, S. (2005). Disability, Workplace Characteristics and Job Satisfaction. International Journal of Manpower, 26:336-349.

Walster, E. Walster, G. and Berscheid, E. (1978). Equity Theory and Research. Boston: Allyn and Bacon.

Warr, P. (1999). Well-Being and the Workplace, in Kahnemann, D. Diener, E. and Schwarz, N. (Eds.), Wellbeing: the Foundations of Hedonic Psychology (p. 392412). New York: Russell Sage Foundation.

Watson, K. and Platt, M. L. (2006). Fairness and the Neurobiology of Social Cognition. Social Justice Research, 19, 186-193.

Wright, E. R. and Perry, B. L. (2006). Sexual Identity Distress, Social Support, and the Health of Gay, Lesbian, and Bisexual Youth. Journal of Homosexuality, 51:81110. 
Table 1. Definition of variables

Variable Definition
name

\begin{tabular}{|c|c|}
\hline S & $\begin{array}{l}1 \text { if the respondent is very dissatisfied; } 2 \text { if the respondent is dissatisfied, } 3 \text { if the } \\
\text { respondent is neither dissatisfied nor satisfied; } 4 \text { if the respondent is satisfied; } 5 \text { if the } \\
\text { respondent is very satisfied }\end{array}$ \\
\hline $\mathrm{L}$ & 1 if individual is lesbian; 0 otherwise \\
\hline G & 1 if individual is gay; 0 otherwise \\
\hline $\mathrm{B}$ & 1 if individual is bisexual; 0 otherwise \\
\hline $\mathrm{OP}$ & $\begin{array}{l}1 \text { if sexual orientation minorities are open about their homosexuality/bisexuality at } \\
\text { work; } 0 \text { if sexual orientation minorities are close at work }\end{array}$ \\
\hline YCO & Years since coming out at work \\
\hline HW & Mean of hourly wages last month before taxes and other deductions (natural log) \\
\hline AGE & Years of age \\
\hline AGESQ & Squared years of age \\
\hline MARR & 1 if individual is married; 0 otherwise \\
\hline CHIL & Number of respondent's children \\
\hline COPART & 1 if individual has a cohabiting partner; 0 otherwise \\
\hline IMM & 1 if individual is an immigrant; 0 otherwise \\
\hline DIS & $\begin{array}{l}1 \text { if individual is limited in kind or amount of work, has a mobility limitation, or has a } \\
\text { personal care limitation; } 0 \text { otherwise }\end{array}$ \\
\hline MHS & $\begin{array}{l}\text { Number of different negative mental health symptom in the last week (Center for } \\
\text { Epidemiology Studies CES - D - } 20 \text { items e.g., depressed, everything an effort, restless } \\
\text { sleep, not happy, lonely, sad, could not get doing, and did not enjoy life) }\end{array}$ \\
\hline SCHOL & 1 if individual has completed minimum mandatory education; 0 otherwise \\
\hline GRAD & 1 if individual has graduated from a high school; 0 otherwise \\
\hline UNIV & 1 if individual has university or a technical school diploma; 0 otherwise \\
\hline $\mathrm{PC}$ & 1 if individual has computer skills; 0 otherwise \\
\hline ENGL & 1 if individual has knowledge of English; 0 otherwise \\
\hline DRIV & 1 if individual has a driving license; 0 otherwise \\
\hline EXPER & Years of actual working experience \\
\hline WHITE & $\begin{array}{l}1 \text { if individual's occupation is among managerial or professional specialties, or the } \\
\text { individual works in a technical, sales, or administrative support position; } 0 \text { otherwise }\end{array}$ \\
\hline BLUE & $\begin{array}{l}1 \text { if individual's occupation is among precision production, craft, or repair occupations, } \\
\text { or the individuals works as an operator, fabricator or labourer; } 0 \text { otherwise }\end{array}$ \\
\hline SERV & $\begin{array}{l}1 \text { if individual's occupation is among food preparation, protective service occupation, } \\
\text { ground cleaning and maintenance occupations, personal care and healthcare support } \\
\text { occupations; } 0 \text { otherwise }\end{array}$ \\
\hline PUBL & 1 if individual is employed in the public sector; 0 otherwise \\
\hline FULL & 1 if individual is a full time employee; 0 otherwise \\
\hline PER & 1 if the individual has a permanent job contract; 0 otherwise \\
\hline WSI & 1 if individual's workplace has more than 50 employees; 0 otherwise \\
\hline TT & 1 if the travel time to job is more than an hour; 0 otherwise \\
\hline
\end{tabular}




$\begin{array}{lllll}\text { Heterosexual } & \text { Gay } & \text { Difference test } & \begin{array}{l}\text { Heterosexual } \\ \text { Women }\end{array} & \text { Lesbians } \\ \text { Men } & \text { Men } & & \text { Difference test }\end{array}$

(1)

(2)

(3)

(4)

Number of observations

Mean hourly earnings $€$

Mean age

Percentage who are married

Mean number of individuals'

children

Percentage of cohabiting

couples

Percentage who are immigrants

Percentage with disability

limitations

Mean value of the adverse

mental health symptoms

Percentage completing

minimum mandatory education

Percentage of high school

graduates

Percentage of university or

technical school graduates

Percentage with computing

skills

Percentage with English skills

Percentage with driving license

Percentage of open gay

men/lesbians at work

Mean years since coming out at work

Mean years of actual working experience

Percentage in white-collar jobs

Percentage in blue-collar jobs

Percentage in service

occupations

Percentage in public sector

Percentage in private sector

Percentage of full-time

employment

Percentage of permanent job

contracts

Percentage of firms with more

than 50 employees

Percentage of employees who

have to travel more than an

hour to reach their workplace

\section{6,516}

8.58

33.94

$65.47 \%$

0.77

$24.96 \%$

$18.65 \%$

$5.05 \%$

1.87

$96.00 \%$

$85.55 \%$

$46.00 \%$

$70.98 \%$

$44.95 \%$

$86.79 \%$

$-$

$-$

13.45

$35.83 \%$

$51.83 \%$

$12.31 \%$

$36.15 \%$

$63.54 \%$

87.01\%

$74.80 \%$

$35.83 \%$

$15.55 \%$

\section{4}

7.84

33.95

$2.96 \%$

0.02

$15.46 \%$

$6.90 \%$

$3.61 \%$

1.88

$96.38 \%$

$81.25 \%$

$43.75 \%$

$79.93 \%$

$43.42 \%$

$92.12 \%$

$70.06 \%$

6.66

13.35

$36.51 \%$

$56.57 \%$

$6.90 \%$

$39.80 \%$

$60.19 \%$

84.91\%

$70.72 \%$

$36.18 \%$

$16.44 \%$ $t=0.15(0.87)$

$Z=0.23(0.80)$

$Z=1.62(0.11)$

$Z=2.81(0.00) * * *$

$Z=1.31(0.18)$

$Z=1.27(0.22)$

$Z=1.12(0.28)$

$Z=1.62(0.12)$

$Z=0.17(0.91)$

5,055

8.09

35.49

$70.62 \%$

0.88

12.56

$9.37 \%$

7.99\%

2.02

$96.36 \%$

$86.52 \%$

$47.63 \%$

$63.62 \%$

$51.01 \%$

$57.92 \%$

-

13.82

$48.80 \%$

$39.66 \%$

$12.50 \%$

$66.58 \%$

$33.32 \%$

$68.86 \%$

$68.03 \%$

$40.76 \%$

$Z=0.46(0.67)$

$16.99 \%$

\section{6}

7.26

34.93

$4.66 \%$

0.08

40.25

$13.55 \%$

$4.23 \%$

$Z=2.1(0.03) * *$

$Z=2.1(0.03)^{* *}$

2.00

$t=0.20(0.83)$

$96.01 \%$

$Z=0.23(0.81)$

$86.01 \%$

$Z=0.02(0.82)$

$49.15 \%$

$Z=0.57(0.65)$

$78.47 \%$

$Z=4.63(0.00) * * *$

$46.61 \%$

$Z=1.32(0.18)$

$72.45 \%$

$Z=4.43(0.00)^{* * *}$

$63.98 \%$

5.70

12.57

$t=2.03(0.04)^{* *}$

$46.61 \%$

$Z=0.78(0.50)$

$39.83 \%$

$Z=0.16(0.95)$

$13.48 \%$

$Z=0.45(0.68)$

$59.94 \%$

$Z=2.15(0.03)^{* *}$

$40.01 \%$

$Z=2.32(0.03) * *$

$73.72 \%$

$Z=1.63(0.11)$

$72.03 \%$

$Z=1.35(0.19)$

$39.40 \%$

$Z=0.41(0.69)$

$15.25 \%$

$Z=0.76(0.49)$

Notes: Data Source, Athens Area Study (2008-2010). We use t-tests to conduct tests for difference in means. We use Z-tests to conduct tests for difference in proportions. P-values are in parenthesis. ***Significant at the 1\% level. ** Significant at the 5\% level. 
Table 3. Distribution of reported job satisfaction measures; heterosexual and gay men

Satisfaction with total pay

Satisfaction with promotion prospects

$\begin{array}{llll}\text { Heterosexual } & \text { Gay } & \text { Heterosexual } & \text { Gay } \\ \text { Men } & \text { Men } & \text { Men } & \text { Men }\end{array}$

(1) (2) (3) (4)

\begin{tabular}{|c|c|c|c|c|}
\hline Very Dissatisfied & $6.37 \%$ & $11.32 \%$ & $15.44 \%$ & $21.02 \%$ \\
\hline Dissatisfied & $21.42 \%$ & $26.40 \%$ & $17.21 \%$ & $25.06 \%$ \\
\hline Neither & $29.57 \%$ & $47.05 \%$ & $26.02 \%$ & $31.40 \%$ \\
\hline Satisfied & $33.17 \%$ & $10.98 \%$ & $35.13 \%$ & $17.05 \%$ \\
\hline Very Satisfied & $9.45 \%$ & $4.03 \%$ & $6.00 \%$ & $5.46 \%$ \\
\hline Observations & 6,516 & 304 & 6,516 & 304 \\
\hline Difference test & $x^{2}=96.4$ & & $x^{2}=48.8$ & \\
\hline
\end{tabular}

\begin{tabular}{|c|c|c|c|c|}
\hline & \multicolumn{2}{|c|}{$\begin{array}{l}\text { Satisfaction with respect received } \\
\text { from supervisor }\end{array}$} & \multicolumn{2}{|c|}{ Total job satisfaction } \\
\hline & $\begin{array}{l}\text { Heterosexual } \\
\text { Men } \\
(5) \\
\end{array}$ & $\begin{array}{l}\text { Gay } \\
\text { Men } \\
(6) \\
\end{array}$ & $\begin{array}{l}\text { Heterosexual } \\
\text { Men } \\
(7) \\
\end{array}$ & $\begin{array}{l}\text { Gay } \\
\text { Men } \\
(8) \\
\end{array}$ \\
\hline Very Dissatisfied & $6.27 \%$ & $18.17 \%$ & $6.22 \%$ & $10.39 \%$ \\
\hline Dissatisfied & $10.41 \%$ & $18.36 \%$ & $20.22 \%$ & $24.59 \%$ \\
\hline Neither & $24.39 \%$ & $35.07 \%$ & $28.36 \%$ & $42.49 \%$ \\
\hline Satisfied & $37.06 \%$ & $23.27 \%$ & $34.83 \%$ & $15.00 \%$ \\
\hline Very Satisfied & $21.87 \%$ & $5.12 \%$ & $10.36 \%$ & $7.52 \%$ \\
\hline Observations & 6,516 & 304 & 6,516 & 304 \\
\hline Difference test & \multicolumn{2}{|c|}{$x^{2}=148.5(0.00)^{* * *}$} & \multicolumn{2}{|c|}{$x^{2}=67.05(0.00)^{* * *}$} \\
\hline
\end{tabular}

Notes: Data Source, Athens Area Study (2008-2010). We use $x^{2}$-tests to conduct tests for distribution of satisfaction. Pvalues are in parenthesis. ***Significant at the $1 \%$ level. 
Satisfaction with total pay

Heterosexual Lesbians

Women

(1)

Very Dissatisfied

Dissatisfied

Neither

Satisfied

Very Satisfied

$11.39 \%$

(2)

$11.32 \%$

$13.97 \%$

$14.06 \%$

$22.91 \%$

$19.30 \%$

$28.30 \%$

Heterosexual

Women

(3)

(4)

$25.30 \%$

$43.40 \%$

$12.31 \%$

$4.40 \%$

$7.38 \%$

$6.19 \%$

Observations

5,055

236

5,055

$x^{2}=52.27(0.00) * * *$

Difference test

$$
x^{2}=114.37(0.00)^{* * *}
$$

$24.31 \%$

$33.12 \%$

$40.27 \%$

$18.20 \%$

Satisfaction with respect received

Total job satisfaction from supervisor

Heterosexual Lesbians Women

(5)

Very Dissatisfied

$4.55 \%$

(6)

$15.37 \%$

$14.31 \%$

$31.33 \%$

$28.18 \%$

Heterosexual

Lesbians

Women

(7)

(8)

Dissatisfied

Neither

Satisfied

$42.73 \%$

$23.40 \%$

$10.80 \%$

236

5,055

236

$\begin{array}{lllll}\text { Observations } & 5,055 & 236 & 5,055 & 236\end{array}$

Difference test $\quad x^{2}=104.07(0.00)^{* * *} \quad x^{2}=43.07(0.00) * * *$

Notes: Data Source, Athens Area Study (2008-2010). We use $x^{2}$-tests to conduct tests for distribution of satisfaction. Pvalues are in parenthesis. $* * *$ Significant at the $1 \%$ level. 
Table 5. Ordered Probit estimates of job satisfaction; men

$\begin{array}{llll}\text { Satisfaction with } & \begin{array}{l}\text { Satisfaction with } \\ \text { total pay }\end{array} & \begin{array}{l}\text { Satisfaction with } \\ \text { promotion } \\ \text { prospects }\end{array} & \begin{array}{l}\text { Total job } \\ \text { from supervisor }\end{array}\end{array}$

\begin{tabular}{|c|c|c|c|c|}
\hline Gay & $-0.241(0.022)^{* * *}$ & $-0.313(0.063)^{* * *}$ & $-0.559(0.048) * * *$ & $-0.243(0.024) * * *$ \\
\hline Bisexual & $-0.290(0.012) * * *$ & $-0.377(0.029)^{* * *}$ & $-0.433(0.155)^{* * *}$ & $-0.276(0.017) * * *$ \\
\hline Wages & $1.225(0.034) * * *$ & $1.727(0.048)^{* * *}$ & $1.833(0.043)^{* * *}$ & $1.248(0.035)^{* * *}$ \\
\hline Age & $-0.023(0.003)^{* * *}$ & $-0.027(0.003)^{* * *}$ & $-0.021(0.005)^{* * *}$ & $-0.025(0.003) * * *$ \\
\hline $\mathrm{Age}^{2}$ & $0.0001(0.00001)^{* * *}$ & $0.0001(0.00001)^{* * *}$ & $0.0001(0.00002)^{* * *}$ & $0.0001(0.00001)^{* * *}$ \\
\hline Married & $0.043(0.007)^{* * *}$ & $0.044(0.007)^{* * *}$ & $0.041(0.007)^{* * *}$ & $0.041(0.009)^{* * *}$ \\
\hline Cohabiting partners & $0.014(0.008)$ & $0.015(0.010)$ & $0.015(0.009)$ & $0.013(0.008)$ \\
\hline Number of children & $0.017(0.015)$ & $0.014(0.014)$ & $0.019(0.012)$ & $0.018(0.014)$ \\
\hline Immigrants & $-0.013(0.006)^{* * *}$ & $-0.015(0.006)^{* * *}$ & $-0.018(0.006) * * *$ & $-0.015(0.007) * * *$ \\
\hline $\begin{array}{l}\text { Graduation from high } \\
\text { school }\end{array}$ & $0.071(0.026)^{* * *}$ & $0.065(0.016)^{* * *}$ & $0.072(0.017)^{* * *}$ & $0.070(0.027)^{* * *}$ \\
\hline $\begin{array}{l}\text { University or technical } \\
\text { school diploma }\end{array}$ & $-0.096(0.014)^{* * *}$ & $0.093(0.015) * * *$ & $0.094(0.013)^{* * *}$ & $-0.093(0.011)^{* * *}$ \\
\hline $\begin{array}{l}\text { Basic knowledge of } \\
\text { computer }\end{array}$ & $-0.013(0.010)$ & $-0.014(0.008)$ & $-0.014(0.010)$ & $0.012(0.009)$ \\
\hline $\begin{array}{l}\text { Basic knowledge of } \\
\text { English }\end{array}$ & $-0.005(0.010)$ & $0.004(0.012)$ & $-0.004(0.009)$ & $-0.004(0.010)$ \\
\hline Driving license & $0.005(0.007)$ & $0.005(0.005)$ & $0.006(0.005)$ & $0.005(0.007)$ \\
\hline Disability status & $-0.016(0.004) * * *$ & $-0.017(0.004)^{* * *}$ & $-0.015(0.003)^{* * *}$ & $-0.015(0.004)^{* * *}$ \\
\hline $\begin{array}{l}\text { Adverse mental health } \\
\text { symptoms }\end{array}$ & $-0.009(0.004)^{* * *}$ & $-0.010(0.005) * * *$ & $-0.010(0.004)^{* * *}$ & $-0.009(0.004)^{* * *}$ \\
\hline $\begin{array}{l}\text { Adverse mental health } \\
\text { symptoms x gay }\end{array}$ & $0.010(0.009)$ & $0.011(0.009)$ & $0.011(0.010)$ & $0.010(0.009)$ \\
\hline Actual work experience & $-0.087(0.009)^{* * *}$ & $-0.085(0.010)^{* * *}$ & $-0.082(0.013) * * *$ & $-0.085(0.011)^{* * *}$ \\
\hline White collar job & $-0.028(0.011)^{* * *}$ & $0.025(0.020)^{* * *}$ & $0.029(0.009)^{* * *}$ & $0.021(0.010)^{* * *}$ \\
\hline Blue collar job & $0.050(0.014)^{* * *}$ & $-0.044(0.012)^{* * *}$ & $-0.042(0.020) * * *$ & $0.052(0.014)^{* * *}$ \\
\hline Public job & $0.045(0.022)^{* * *}$ & $0.045(0.024)^{*}$ & $0.049(0.021)^{* * *}$ & $0.047(0.025)^{* * *}$ \\
\hline Full time employment & $0.041(0.032)$ & $0.040(0.033)$ & $0.038(0.030)$ & $0.039(0.030)$ \\
\hline Workplace size & $0.018(0.013)$ & $0.019(0.012)$ & $0.017(0.012)$ & $0.019(0.012)$ \\
\hline Time travel to work & $0.054(0.042)$ & $0.055(0.040)$ & $0.055(0.043)$ & $0.055(0.041)$ \\
\hline Pseudo $\mathrm{R}^{2}$ & 0.007 & 0.006 & 0.007 & 0.010 \\
\hline Observations & 6,874 & 6,874 & 6,874 & 6,874 \\
\hline
\end{tabular}

Notes: Data Source, Athens Area Study (2008-2010). Standard errors are in parenthesis. ${ }^{* * *}$ Significant at the $1 \%$ level. *Significant at the $10 \%$ level. 
Table 6. Ordered Probit estimates of job satisfaction; women

$\begin{array}{llll}\text { Satisfaction with } & \begin{array}{l}\text { Satisfaction with } \\ \text { total pay }\end{array} & \begin{array}{l}\text { Satisfaction with } \\ \text { respect received } \\ \text { prospects }\end{array} & \begin{array}{l}\text { Total job } \\ \text { satisfaction }\end{array} \\ & \text { from supervisor } & \end{array}$

\begin{tabular}{|c|c|c|c|c|}
\hline Lesbian & $-0.130(0.019)^{* * *}$ & $-0.210(0.032)^{* * *}$ & $-0.381(0.020)^{* * *}$ & $-0.203(0.037)^{* * *}$ \\
\hline Bisexual & $-0.174(0.005) * * *$ & $-0.181(0.060)^{* * *}$ & $-0.401(0.042)^{* * *}$ & $-0.229(0.061)^{* * *}$ \\
\hline Wages & $1.362(0.071)^{* * *}$ & $1.782(0.073)^{* * *}$ & $1.892(0.069) * * *$ & $1.367(0.066)^{* * *}$ \\
\hline Age & $-0.022(0.003) * * *$ & $-0.025(0.003)^{* * *}$ & $-0.020(0.004)^{* * *}$ & $-0.023(0.003) * * *$ \\
\hline $\mathrm{Age}^{2}$ & $0.0001(0.00001)^{* * *}$ & $0.0001(0.00001)^{* * *}$ & $0.0001(0.00002)^{* * *}$ & $0.0001(0.00001)^{* * *}$ \\
\hline Married & $0.040(0.010)^{* * *}$ & $0.040(0.011)^{* * *}$ & $0.039(0.011)^{* * *}$ & $0.039(0.011)^{* * *}$ \\
\hline Cohabiting partners & $0.021(0.014)$ & $0.025(0.015)$ & $0.025(0.020)$ & $0.023(0.021)$ \\
\hline Number of children & $0.015(0.013)$ & $0.012(0.012)$ & $0.017(0.011)$ & $0.016(0.014)$ \\
\hline Immigrants & $-0.016(0.004) * * *$ & $-0.018(0.004)^{* * *}$ & $-0.020(0.003)^{* * *}$ & $-0.019(0.003) * * *$ \\
\hline $\begin{array}{l}\text { Graduation from high } \\
\text { school }\end{array}$ & $0.068(0.016)^{* * *}$ & $0.63(0.014)^{* * *}$ & $0.069(0.015)^{* * *}$ & $0.065(0.019)^{* * *}$ \\
\hline $\begin{array}{l}\text { University or technical } \\
\text { school diploma }\end{array}$ & $-0.085(0.016)^{* * *}$ & $0.086(0.018)^{* * *}$ & $0.089(0.015)^{* * *}$ & $-0.087(0.016)^{* * *}$ \\
\hline $\begin{array}{l}\text { Basic knowledge of } \\
\text { computer }\end{array}$ & $-0.012(0.009)$ & $0.011(0.008)$ & $-0.012(0.009)$ & $-0.011(0.009)$ \\
\hline $\begin{array}{l}\text { Basic knowledge of } \\
\text { English }\end{array}$ & $-0.004(0.010)$ & $-0.004(0.010)$ & $0.004(0.010)$ & $-0.004(0.010)$ \\
\hline Driving license & $0.004(0.005)$ & $0.003(0.003)$ & $0.004(0.004)$ & $0.005(0.004)$ \\
\hline Disability status & $-0.020(0.003)^{* * *}$ & $-0.021(0.003)^{* * *}$ & $-0.022(0.003)^{* * *}$ & $-0.021(0.003) * * *$ \\
\hline $\begin{array}{l}\text { Adverse mental health } \\
\text { symptoms }\end{array}$ & $-0.011(0.003)^{* * *}$ & $-0.012(0.004)^{* * *}$ & $-0.013(0.005)^{* * *}$ & $-0.012(0.004)^{* * *}$ \\
\hline $\begin{array}{l}\text { Adverse mental health } \\
\text { symptoms x lesbian }\end{array}$ & $0.012(0.012)$ & $0.011(0.011)$ & $0.012(0.009)$ & $0.011(0.010)$ \\
\hline Actual work experience & $-0.075(0.011)^{* * *}$ & $-0.075(0.012)^{* * *}$ & $-0.071(0.011)^{* * *}$ & $-0.072(0.0110)^{* * *}$ \\
\hline White collar job & $-0.026(0.012) * * *$ & $0.023(0.010)^{* * *}$ & $0.024(0.011)^{* * *}$ & $0.021(0.011)^{* * *}$ \\
\hline Blue collar job & $0.046(0.010)^{* * *}$ & $-0.039(0.011) * * *$ & $-0.039(0.019) * * *$ & $0.043(0.011)^{* * *}$ \\
\hline Public job & $0.039(0.016) * * *$ & $0.040(0.016)^{*}$ & $0.040(0.018)^{* * *}$ & $0.040(0.017)^{* * *}$ \\
\hline Full time employment & $0.056(0.045)$ & $0.058(0.041)$ & $0.058(0.049)$ & $0.058(0.044)$ \\
\hline Workplace size & $0.019(0.022)$ & $0.020(0.021)$ & $0.020(0.020)$ & $0.019(0.022)$ \\
\hline Time travel to work & $0.048(0.053)$ & $0.048(0.056)$ & $0.050(0.056)$ & $0.048(0.055)$ \\
\hline Pseudo $\mathrm{R}^{2}$ & 0.006 & 0.009 & 0.011 & 0.006 \\
\hline Observations & 5,303 & 5,303 & 5,303 & 5,303 \\
\hline
\end{tabular}

Notes: Data Source, Athens Area Study (2008-2010). Standard errors are in parenthesis.

***Significant at the 1\% level. *Significant at the $10 \%$ level. 
Table 7. Ordered Probit estimates of job satisfaction differences; heterosexuals, openly gay men/lesbians at the present job, closeted gay men/lesbians and the present job

$\begin{array}{llll}\begin{array}{l}\text { Satisfaction with } \\ \text { total pay }\end{array} & \begin{array}{l}\text { Satisfaction with } \\ \text { promotion }\end{array} & \begin{array}{l}\text { Satisfaction with } \\ \text { respect received from } \\ \text { prospects }\end{array} & \begin{array}{l}\text { Total job } \\ \text { satisfaction }\end{array} \\ & & \end{array}$

\section{Men}

I. Openly gay men at the $-0.231(0.021)^{* * *}$

$-0.305(0.031)^{* * *}$

$-0.552(0.021)^{* * *}$

$-0.232(0.018)^{* * *}$ present job vs. heterosexual men

II. Closeted gay men at the $-0.252(0.019)^{* * *}$ $-0.319(0.038)^{* * *}$ $-0.562(0.027)^{* * *}$ $-0.251(0.014)^{* * *}$ present job vs. heterosexual men

III. Openly gay men at the $0.016(0.009)^{*}$ $0.028(0.012)^{* * *}$ $0.026(0.010)^{* * *}$ $0.028(0.012)^{* * *}$ present job vs. closeted gay men at the present job

\section{Women}

IV. Openly lesbians at the $-0.126(0.023)^{* * *}$ $-0.203(0.039)^{* * *}$ $-0.371(0.027)^{* * *}$ $-0.192(0.026)^{* * *}$ present job vs. heterosexual women

V. Closeted lesbians at the $-0.136(0.026)^{* * *}$ $-0.216(0.032)^{* * *}$ present job vs.

Heterosexual women

VI. Openly lesbians at the $0.013(0.013)^{* *}$ $0.021(0.010)^{* * *}$ $0.020(0.008)^{* * *}$ $0.021(0.010)^{* * *}$ present job vs. closeted lesbians at the present job

\footnotetext{
Notes: Data Source, Athens Area Study (2008-2010). Standard errors are in parenthesis.***Significant at the 1\% level.** Significant at the $5 \%$ level. *Significant at the $10 \%$ level. Each cell is a separate job-satisfaction -regression outcome. The value printed in rows I,II,IV and V is the coefficient that only has openly or closeted gay men/lesbians and heterosexuals in the sample. The value printed in rows III and VI is the coefficient that only has openly and closeted gay men/lesbians in the sample. Each regression incorporates the same exogenous variables as in Tables 5 and 6.
} 
Table 8. Ordered Probit estimates of job satisfaction differences; years since disclosure of homosexuality at the present job

\begin{tabular}{llll}
$\begin{array}{l}\text { Satisfaction with } \\
\text { total pay }\end{array}$ & $\begin{array}{l}\text { Satisfaction with } \\
\text { promotion prospect }\end{array}$ & $\begin{array}{l}\text { Satisfaction with } \\
\text { respect received } \\
\text { from supervisor }\end{array}$ & $\begin{array}{l}\text { Total job } \\
\text { satisfaction }\end{array}$ \\
\hline & & & \\
\hline
\end{tabular}

\begin{tabular}{|c|c|c|c|c|}
\hline $\begin{array}{l}\text { I. Gay men who have disclosed } \\
\text { their homosexuality at the } \\
\text { present job less than three years } \\
\text { ago } \quad \text { vs. heterosexual men }\end{array}$ & $-0.238(0.024)^{* * *}$ & $-0.308(0.027) * * *$ & $-0.551(0.024)^{* * *}$ & $-0.238(0.029) * * *$ \\
\hline $\begin{array}{l}\text { II. Gay men who have disclosed } \\
\text { their homosexuality at the present } \\
\text { job more than three years ago } \\
\text { vs. heterosexual men }\end{array}$ & $-0.231(0.028)^{* * *}$ & $-0.298(0.033) * * *$ & $-0.543(0.036)^{* * *}$ & $-0.231(0.028) * * *$ \\
\hline $\begin{array}{l}\text { III. Gay men who have disclosed } \\
\text { their homosexuality at the } \\
\text { present job less than three years } \\
\text { ago vs. gay men who } \\
\text { have disclosed their } \\
\text { homosexuality at the present job } \\
\text { more than three years ago }\end{array}$ & $-0.015(0.009) * * *$ & $-0.014(0.009) * * *$ & $-0.019(0.005)^{* * *}$ & $-0.021(0.008)^{* * *}$ \\
\hline
\end{tabular}

Women

IV. Lesbians who have disclosed

$-0.124(0.025)^{* * *}$

$-0.205(0.027) * * *$

$-0.376(0.031)^{* * *}$

$-0.197(0.028)^{* * *}$

their homosexuality at the present job less than three years ago vs. heterosexual women

V. Lesbians who have disclosed their homosexuality at the present job more than three years ago vs. heterosexual women

VI. Lesbians who have disclosed their homosexuality at the present job less than three years ago vs. lesbians who have disclosed their homosexuality at the present job more than three years ago

Notes: Data Source, Athens Area Study (2008-2010). Standard errors are in parenthesis.***Significant at the 1\%. level. Each cell is a separate job-satisfaction- regression outcome. The value printed in rows I,II,IV and V is the coefficient that only has gay men/lesbians who have disclosed their homosexuality at the present job less or more than three years ago and heterosexuals in the sample. The value printed in rows III and VI is the coefficient that only has gay men/lesbians who have disclosed their homosexuality at the present job less than three years ago and gay men/lesbians who have disclosed their homosexuality at the present job more than three years ago in the sample. Each regression incorporates the same variables as in Tables 5 and 6. 
Table 9. OLS estimates of hourly wages (natural log); gay men/lesbians and heterosexuals

\begin{tabular}{lll}
\hline & Men & Women \\
\hline Homosexuality & $-0.049(0.016)^{* * *}$ & $-0.081(0.014)^{* * *}$ \\
Bisexuality & $-0.057(0.021)^{* * *}$ & $-0.063(0.027)^{* * *}$ \\
Age & $0.023(0.010)^{* * *}$ & $0.017(0.008)^{* * *}$ \\
Age $^{2}$ & $-0.0004(0.0000)^{* * *}$ & $-0.0004(0.0000)^{* * *}$ \\
Married & $0.034(0.006)^{* * *}$ & $0.031(0.011)^{* * *}$ \\
Number of children & $0.031(0.010)^{* * *}$ & $0.026(0.012)^{* * *}$ \\
Immigrants & $-0.042(0.016)^{* * *}$ & $-0.059(0.005)^{* * *}$ \\
Graduation from high school & $0.087(0.010)^{* * *}$ & $0.081(0.019)^{* * *}$ \\
University or technical school diploma & $0.103(0.007)^{* * *}$ & $0.094(0.031)^{* * *}$ \\
Basic knowledge of computer & $0.013(0.002)^{* * *}$ & $0.009(0.003)^{* * *}$ \\
Basic knowledge of English & $0.010(0.002)^{* * *}$ & $0.009(0.004)^{* * *}$ \\
Driving license & $0.032(0.007)^{* * *}$ & $0.012(0.007)^{*}$ \\
Disability status & $-0.056(0.024)^{* * *}$ & $-0.063(0.015)^{* * *}$ \\
Adverse mental health symptoms & $-0.021(0.011)^{* *}$ & $-0.017(0.009)^{* *}$ \\
Actual work experience & $0.029(0.003)^{* * *}$ & $0.024(0.005)^{* * *}$ \\
White collar job & $0.164(0.049)^{* * *}$ & $0.131(0.053)^{* * *}$ \\
Public job & $0.021(0.008)^{* * *}$ & $0.019(0.007)^{* * *}$ \\
Full time employment & $0.072(0.017)^{* * *}$ & $0.041(0.020)^{* * *}$ \\
Adj. R ${ }^{2}$ & 0.781 & 0.744 \\
Observations & 6,874 & 5,303 \\
\hline
\end{tabular}

Notes: Data Source, Athens Area Study (2008-2010). Standard errors are in parenthesis.

***Significant at the $1 \%$ level. ${ }^{* *}$ Significant at the $5 \%$ level. *Significant at the $10 \%$ level 
Table 10. OLS estimates of wage differences between sexual orientations per each satisfaction scale component regarding total job satisfaction

Hourly wages (ln)

Gay men vs heterosexual men

Very dissatisfied employees $\quad-0.058(0.021)^{* * *}$

Dissatisfied employees $\quad-0.046(0.008) * * *$

Neither dissatisfied $\quad-0.041(0.008) * * *$

nor satisfied employees

Satisfied employees $\quad-0.022(0.017)$

Very satisfied employees $\quad 0.014(0.012)$

Lesbians vs heterosexual women

Very dissatisfied employees $\quad-0.097(0.030)^{*}$

Dissatisfied employees $\quad-0.090(0.035)^{* * *}$

Neither dissatisfied $\quad-0.072(0.008) * * *$

nor satisfied employees

Satisfied employees

$-0.030(0.017)^{* *}$

Very satisfied employees

$-0.026(0.015)^{*}$

Notes: Data Source, Athens Area Study (2008-2010). Standard errors are in parenthesis. ***Significant at the 1\% level. ** Significant at the 5\% level. *Significant at the 10\% level. Each cell is a separate wage-regression outcome. Each regression incorporates the same variables as in Table 9. 
Table 11. OLS estimates of wage differences; openly gay men/lesbians and closeted gay men/lesbians at the present job

Hourly wages $(\ln )$

Men

I. Openly gay men at the present job

$-0.031(0.010) * * *$

vs.

closeted gay men at the present job

II. Gay men who have disclosed their

homosexuality at the present job less

$-0.015(0.008) * *$

than three years ago

vs.

gay men who have disclosed their

homosexuality at the present job more

than three years ago

\section{Women}

III. Openly lesbians at the present job $\quad-0.053(0.016) * * *$

vs.

closeted lesbians at the present job

IV. Lesbians who have disclosed their $-0.011(0.005) * * *$

homosexuality at the present job less

than three years ago

vs.

lesbians who have disclosed their

homosexuality at the present job more

than three years ago

Notes: Data Source, Athens Area Study (2008-2010). Standard errors are in parenthesis.***Significant at the $1 \%$ level.** Significant at the $5 \%$ level. Each cell is a separate wage regression. The value printed in rows II and IV is the coefficient that only has gay men/lesbians who have disclosed their homosexuality at the present job less than three years ago and gay men/lesbians who have disclosed their homosexuality at the present job more than three years ago in the sample. The value printed in rows I and III is the coefficient that only has openly and closeted gay men/lesbians in the sample. Each regression incorporates the same exogenous variables as in Table 9. 